\title{
An In-Vitro Study of Syzygium cumini Seed Extract on Glucose Uptake Activity in L-6 Cell Lines
}

\section{Narmatha and S. Maneemegalai*}

Department of Biochemistry, Government Arts and Science College (Women) [formerly Bharathidasan University Constituent College for Women], Orathanadu - 614 625, Thanjavur District, Tamil Nadu, India.

\begin{abstract}
Diabetes mellitus is the most common endocrine disorder. The plant Syzygium cumini has been used in traditional medicine for the treatment of diabetes. The present study investigated the effect of ethanol extract of $S$. cumini seeds on uptake of glucose by L- 6 rat skeletal muscle cells. $S$. cumini seeds were extracted with varying solvents and quantitative phytochemical analysis was carried out, ethanol extract of seeds exhibited higher content of tested phytochemicals. The effect of different concentrations $(300 \mu \mathrm{g} / \mathrm{ml}-1000 \mu \mathrm{g} / \mathrm{ml})$ of ethanol extract of seeds were studied on glucose uptake activity of L-6 rat skeletal muscle cells. It was observed that with the increase in concentration, the glucose uptake activity was also increased. The results of the study supports and demonstrates the antidiabetic potential of ethanol seed extracts of Syzygium cumini utilizing in vitro model.
\end{abstract}

Keywords: Diabetes mellitus, Syzygium cumini, phytochemicals, glucose uptake, L-6 cells

Article Info: Received 29 July 2019; Review Completed 24 Aug 2019; Accepted 29 Aug 2019; Available online 30 Aug 2019

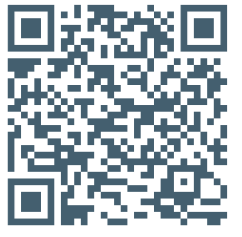

\section{Cite this article as:}

Narmatha M, Maneemegalai S, An In-Vitro Study of Syzygium cumini Seed Extract on Glucose Uptake Activity in L-6 Cell Lines, Journal of Drug Delivery and Therapeutics. 2019; 9(4-A):256-259 http://dx.doi.org/10.22270/jddt.v9i4-A.3419

\section{*Address for Correspondence:}

(Women) [formerly Bharathidasan University Constituent College for Women], Orathanadu - 614 625, Thanjavur Dt, Tamil Nadu.

\section{INTRODUCTION}

Diabetes mellitus is one of the common endocrine disorders either due to the defective production of insulin or insufficient response to insulin leads to hyperglycemic condition. It causes severe secondary complications like heart attack, stroke, neuropathy, retinopathy and nephropathy ${ }^{1}$. In the year 2000, India had the highest number of people with diabetes mellitus in the world $(31.7$ million) followed by China and United States of America ${ }^{2}$. World Health Organization (WHO) foresees increase in diabetic population upto 300 million or more by the year $2025^{3}$.

Sulphonylureas, biguanides, $\alpha$ glucosidase inhibitors are some of the standard drugs used for the treatment of Diabetes mellitus. Head ache, nausea, vomiting, diarrhea, abdominal pain and abnormal weight gain are some of the side effects occur due to the intake of these drugs ${ }^{4}$. The above drugs were considered as not safe during pregnancy 5 .

Traditional medical practices all over the world utilize various herbs for treating diabetes and to prevent complications. With the widespread use of allopathic medicines and the overall side effects and complications, researchers focused their attention towards herbal remedies because of their efficacy, easy availability and low cost. Many experiments have been conducted on herbal plants and were found to be anti diabetic 6 .

Skeletal muscle is a major tissue and it plays an important role in maintaining whole body glucose homeostasis and it is a primary target tissue for insulin action ${ }^{7}$. Secondary complications in diabetes are prevented by controlling the post prandial hyperglycemia. Insulin increases the uptake of glucose by skeletal muscle, Impaired glucose uptake in skeletal muscle is the main reason for the development of Type II diabetes ${ }^{8}$.

Syzygium cumini (L.) is one of an important traditional medicinal plant of India, belongs to Myrtaceae family. It is commonly known as Java plum, Jamun and Indian blackberry. It is called as Naaval in Tamil language. The plants leaves, fruits, seeds and bark has medicinal value. Antidiabetic $^{9}$, anticancer ${ }^{10,11}$, anti inflammatory ${ }^{12}$ activities of seeds of Syzygium cumini, antioxidant and antibacterial ${ }^{13}$ activities have also been reported earlier.

The present study deals with the quantitative phytochemical analysis and the effect of ethanol extract of S.cumini seeds on 
the glucose uptake studies of rat skeletal muscle cells (L6cells).

\section{MATERIALS AND METHODS}

The fruits of Syzygium cumini were collected from the villages of Orathanadu taluk,Thanjavur District, Tamil Nadu, India. The fruits were washed with water and pulp portion of the fruit was removed. Seeds were collected, washed thoroughly with distilled water and dried under shades and powdered using a pulverizer.

Solvent extraction of Syzygium cumini seed powder: The powdered seed sample was extracted with different solvents such as ethanol, acetonitrile, ethyl acetate, dichloro methane and hexane. $24 \mathrm{~h}$ after the addition of solvent, insoluble content of the sample was separated by centrifugation at $3000 \mathrm{rpm}$ for 15 minutes. The supernatant was rotary vacuum evaporated at $60^{\circ} \mathrm{C}$ and dried by lyophilization and stored at dry condition. The dry weight of the various solvent extracted sample per $100 \mathrm{~g}$ of seed powder was measured. Then quantitative analysis of total alkaloids ${ }^{14}$, total phenols ${ }^{15}$, total flavonoids ${ }^{16}$, total tannins ${ }^{17}$, total saponins ${ }^{18}$ and total steroids ${ }^{19}$ were conducted.

\section{Glucose uptake activity}

Sample preparation for cell culture: Required sample was dissolved completely in 5\% DMEM using cyclomixer. After that, the sample solution was filtered through $0.22 \mu \mathrm{m}$ millipore syringe filter to ensure the sterility.

Preparation of cell culture: L6 rat skeletal muscle cell line culture was purchased from the American Type Culture Collection (ATCC ${ }^{\circ}$ CRL1458 ${ }^{\mathrm{TM}}$ ) and maintained in DMEM (Dulbecco's Modified Eagle's medium). The L6 myoblasts was cultured in $25 \mathrm{~cm}^{2}$ tissue culture flask with DMEM supplemented with 10\% FBS, $2 \mathrm{mM}$ L-glutamine and antibiotics viz., $50 \mathrm{IU} / \mathrm{L}$ penicillin and $0.05 \mathrm{~g} / \mathrm{L}$ streptomycin. Cultured cell line was kept at $37^{\circ} \mathrm{C}$ in a humidified $5 \% \mathrm{CO}_{2}$ incubator. Once the myoblasts were grown to confluence in 24-well plates, the medium was replaced with Dulbecco's modified Eagle's medium with $2 \%$ horse serum (HS) to induce myotube differentiation. From the L6 confluent cells, $100 \mu \mathrm{l}$ cell suspension $\left(5 \times 10^{4}\right.$ cells/well) were suspended in $10 \%$ growth medium in 24-well tissue culture plate and incubated at $37^{\circ} \mathrm{C}$ in a humidified $5 \% \mathrm{CO}_{2}$ incubator. The incubation containing the fully differentiated myotubes were serum-starved for $18 \mathrm{~h}$ in Dulbecco's modified Eagle's medium containing $0.2 \%$ bovine serum albumin prior to experiments. Glucose uptake activity was performed with the slight modifications of standard method ${ }^{20}$ with different concentration of ethanol seed extract $(300 \mu \mathrm{g} / \mathrm{ml}-1000$ $\mu \mathrm{g} / \mathrm{ml}$ ), $100 \mathrm{nM}$ of insulin as standard, control well and measured amount of added glucose ${ }^{20}$. Glucose in the culture medium was assayed by glucose oxidase - peroxidase method 21 . Results were expressed as $\%$ of glucose uptake by the L6 cells.

\section{RESULT}

Table 1 presented the dry weight of various solvent extract of S.cumini seeds. It was observed that acetonitrile extract exhibited a highest amount of yield and hexane extract was found to be the least. When these various solvent extracts were utilized for quantitative analysis of various phytochemicals (Table 2), ethanol extracts yielded higher quantity of all tested phytochemicals.

Table 1 Dry weight of solvent extracted Syzygium cumini (L.) seeds per $100 \mathrm{~g}$ of sample

\begin{tabular}{|l|l|}
\hline Solvent & Dry weight $(\mathrm{g} / 100 \mathrm{~g})$ \\
\hline Ethanol & 1.89 \\
\hline Acetonitrile & 2.33 \\
\hline Ethyl acetate & 1.72 \\
\hline Dichloromethane & 1.69 \\
\hline Hexane & 1.54 \\
\hline
\end{tabular}

Table 2 presented the quantitative analysis of phytochemicals total alkaloids, total phenol, total flavonoids, total tannin, total saponin and total steroids. Ethanol extracted seeds yield of phytochemicals was found to be in higher amount compared to all other tested extracts. Among the six tested phytochemicals, total alkaloids was found be in higher amount followed by total phenol, total flavonoids, total steroids, total tannin and total saponin. Ethanol extract was utilized for invitro glucose uptake study.

Effect of various concentration of ethanol extract of seeds of Syzygium cumini for the uptake of glucose by L6 rat skeletal muscle cells was shown in Table 3 . Varied concentration of ethanol extract from $300-1000 \mu \mathrm{g} / \mathrm{ml}$ with the incremental addition of $100 \mu \mathrm{g} / \mathrm{ml}$ was tested with the cultured L6 cells. $100 \mathrm{nM}$ of insulin was used as a standard positive control along with another well without any addition to the cells.

It was shown that with the increase in the amount of S.cumini extract concentration, there was a increase in the glucose uptake activity. $1000 \mu \mathrm{g} / \mathrm{ml}$ ethanol extract observed to possess the maximum (29.9\%) activity of glucose uptake in the cells. Whereas insulin was found to increase $42.1 \%$ uptake of glucose.

Table 2: Quantitative phytochemical analysis of different solvent extracted Syzygium cumini seed powder (Values are expressed as Mean \pm SD of triplicates)

\begin{tabular}{|l|l|l|l|l|l|}
\hline \multirow{3}{*}{ Phyto chemicals } & \multicolumn{5}{|c|}{ Phytochemicals (mg/gram of solvent extract) } \\
\cline { 2 - 6 } & Ethanol & Acetonitrile & Ethyl acetate & Dichloro methane & Hexane \\
\hline Total alkaloid & $159.65 \pm 8.2$ & $125.6 \pm 7.4$ & $123.58 \pm 7.1$ & $96.63 \pm 6.2$ & $61.72 \pm 4.9$ \\
\hline Total phenol & $141.5 \pm 8.0$ & $60.0 \pm 5.5$ & $73.65 \pm 6.3$ & $59.49 \pm 4.5$ & $47.69 \pm 3.9$ \\
\hline Total flavonoid & $94.26 \pm 6.1$ & $73.45 \pm 6.9$ & $64.61 \pm 5.5$ & $51.89 \pm 4.7$ & $59.39 \pm 5.1$ \\
\hline Total tannin & $65.35 \pm 4.3$ & $42.73 \pm 2.9$ & $57.34 \pm 3.9$ & $59.99 \pm 5.2$ & $38.75 \pm 3.1$ \\
\hline Total saponin & $14.53 \pm 1.0$ & $13.48 \pm 1.0$ & $13.0 \pm 1.1$ & $10.95 \pm 0.8$ & $6.28 \pm 0.4$ \\
\hline Total steroids & $67.6 \pm 5.1$ & $41.68 \pm 3.1$ & $78.36 \pm 6.3$ & $62.44 \pm 4.9$ & $71.29 \pm 5.6$ \\
\hline
\end{tabular}


Table 3: Enhanced glucose uptake activities of ethanol extract concentrations from the seeds of Syzygium cumini against L6 rat skeletal muscle cells (Values are expressed as Mean \pm SD of triplicates)

\begin{tabular}{|l|l|}
\hline $\begin{array}{l}\text { Ethanol extract of S.cumini } \\
\text { seeds (concentration } \mu \mathrm{g} / \mathrm{ml} \text { ) }\end{array}$ & $\begin{array}{l}\text { \% Glucose } \\
\text { uptake }\end{array}$ \\
\hline 1000 & $29.9 \pm 1.27$ \\
\hline 900 & $26.8 \pm 1.12$ \\
\hline 800 & $24.5 \pm 1.02$ \\
\hline 700 & $20.1 \pm 0.89$ \\
\hline 600 & $16.2 \pm 0.73$ \\
\hline 500 & $13.0 \pm 0.51$ \\
\hline 400 & $10.3 \pm 0.31$ \\
\hline 300 & $8.9 \pm 0.19$ \\
\hline Insulin & $42.1 \pm 1.89$ \\
\hline Control & $6.9 \pm 0.21$ \\
\hline
\end{tabular}

\section{DISCUSSION}

Earlier qualitative studies in our laboratory on the seeds extract of S. cumini revealed the presence of alkaloid, phenol, flavonoid, tannin, saponin, Steroids, cardiac glycosides, anthraquinone glycosides, oils and fats, lignin, terpenoids, phlobatannins, coumarin, quinine, sugar and amino acids 22 Skeletal muscle being the primary consumer of glucose, the effect of plant extract on the uptake of glucose by skeletal muscle cell was studied. Skeletal muscle is the major site of glucose uptake and utilization ${ }^{23}$. In Type 2 Diabetes mellitus, insulin stimulated skeletal muscle uptake is found defective 8 . It was reported that in type 2 diabetes mellitus patients, the insulin resistance defect lies at the level of transport phosphorylation 24,25 . Generally stimulated insulin receptor leads to the phosphorylation of insulin responsive substrate1, this leads to activation of phosphatidyl inositol 3 kinase which phosphorylates Akt2. It stimulates translocation of GLUT4 glucose transporter storage vesicles to the plasma membrane and insertion of GLUT4 enabling glucose transport and glycogen synthesis 26 . Defect in the insulin signaling pathway results in the suppression of translocation of glucose transporter storage vesicles (GSV) have been observed in obese and type 2 diabetic patients 27 . Samir et al ${ }^{28}$ have observed that natural supplements like fenugreek, ginseng, cinnamon, biotin and alpha lipoic acid were found to stimulate glucose uptake in skeletal muscle through GLUT transporter. Earlier studies have reported the effect of medicinal plants on the enhanced uptake of glucose through GLUT4 translocation29,30. In medicinal plants, phytochemicals play a more important role in their medicinal activity. The role of phytochemicals in insulin signaling pathway have been reported by many researchers. Anitha and Rajadurai ${ }^{20}$ have reported that flavonoids ie chrysin, a flavone enhanced glucose uptake in L6 cell lines by activating $\mathrm{PPAR}_{\gamma}$ thereby increasing the expression of glucose transporter GLUT4. Triveni et al ${ }^{31}$ have reported that the leaves extract of Scoparia dulcis significantly stimulated glucose uptake in L6 myotubes and was found to increase insulin signaling pathway by inducing activatory phosphorylation status of IRS- 1 and Akt in the treatment of type 2 diabetes. Xu et al 32 oberved the hypoglycemic and hypolipidemic effects of total saponins from Stauntonia chinensis in diabetic $\mathrm{db} / \mathrm{db}$ mice. Saponins exhibited hypoglycemic activity partly due to the activation of GLUT4. Tannic acid (components of tannin) stimulates the glucose transport in 3T3 - L1 cells ${ }^{33}$. Glucose uptake in $\mathrm{C} 2 \mathrm{C} 12$ skeletal muscle cells was enhanced by steroidal alkaloids from Veratrum nigrum ${ }^{34}$ and Gossypol from cotton seeds (a natural phenol) 35. It was also observed that the crude ethanol extract of Syzygium jambolanum seed increased the glucose uptake by yeast cells in vitro at lower concentration ${ }^{36}$. The L6 cell lines derived from skeletal muscle serves as a good model for glucose uptake study ${ }^{37}$. There was a fourfold increase in the uptake of glucose at the maximum concentration of ethanol extract of Syzygium cumini seeds whereas insulin exhibited 6 fold increase over the normal control in the present in vitro study.

\section{CONCLUSION}

The results of the present study proved that the ethanol extract of Syzygium cumini seeds enhances the uptake of glucose by the cells in in vitro condition. This activity might be due to the presence of rich amount of phytochemicals present in the seeds. The present study supports the beneficial effect of seeds of Syzygium cumini as observed and practiced in the traditional medicine.

\section{REFERENCES}

1. Patel DK, Kumar R, Prasad SK, Sairam K, Hemalatha S, Antidiabetic and in vitro antioxidant potential of Hybanthus enneaspermus (Linn)F. Muell in streptozotocin induced diabetic rats. Asian Pacific Journal of Tropical Biomedicine, 2011; 1(4) $316-322$.

2. Kaveeshwar SA, Jon Cornwall, The current state of Diabetes mellitus in India. The Australian Medical Journal, 2014; 7(1), 14, $45-48$.

3. Sy GY, Cisse A, Nongonierma RB, Sarr M, Mbodj NA, Faye B, Hypoglycemic and antidiabetic activity of acetonic extract of Vernonia colorata leaves in normoglycemic and alloxan induced diabetic rats. Journal of Ethnopharmacology, 2005; 98(1-2) : $171-175$.

4. Sangeetha DN, Rajamani S, In vitro antidiabetic activity of methanolic leaf extract of Indianthus virgatus (Roxb.) Suksathan and Borchs by Glucose uptake method, Pharmacognosy Journal, 2019: 11(4): 674 - 677.

5. Anbu NM, Vel Pandian V, Anti diabetic activity of polyherbal formulation aavaraiyathichurnam in alloxan induced diabetic rats. International Journal of Toxicological and Pharmacological Research, 2012; 4: 77 - 80.

6. Grover JK, Yadav S, Vats V, Medicinal plants of India with antidiabetic potential, Journal of Ethanopharmacology, 2002; 81: $81-90$.

7. Rajeswari R, Sridevi M, Study of In vitro glucose uptake activity of isolated compounds from hydro alcoholic leaf extract of Cardiospermum halicacabum Linn, 2014; 6(11): 181 - 185.

8. Baron AD, Laakso M, Brechtel G, Edelman SV, Reduced capacity and affinity of skeletal muscle for insulin mediated glucose uptake in non insulin dependent diabetic subjects. Effects of insulin therapy, Journal of Clinical Investigation, 1991; 87: 1186 $-1194$.

9. Modi DC, Patel JK, Shah BN , Nayak BS, Pharmacognostic Studies of the Seed of Syzygium cumini, Pharma Science Monitor, 2010; 1: 20-26.

10. Parmar J, Sharma P, Verma P, Sharma P , Goyal PK, Chemopreventive action of Syzygium cumini on DMBA -induced Skin Papillomagenesis in mice. Asian Pacific Journal of Cancer Prevention, 2010; 11: 261-265.

11. Sunil SY, Meshram GA, Dattatreya Shinde, Patil RC, Sonal M. Manohar, Madhav V Upadhye. Antibacterial and anti cancer activity of bioactive fraction of Syzygium cumini L. seeds. HAYATI Journal of Biosciences, 2011; 18(3), 118 - 122.

12 Kumar A, Ilavarasan R, Jayachandran T, Decaraman M, Kumar RM, Aravindhan P, Padmanabhan N , Krishan MRV, Antiinflammatory activity of Syzygium cumini, African Journal of Biotechnology, 2008; 7: 941-943.

13. Joyita B, Narendhirakannan RT, Phytochemical analyses, antibacterial, in vitro antioxidant and cytotoxic activities of ethanolic extract of Syzygium cumini (L.) seed extract, 
International Journal of Pharmaceutical Sciences and Research, 2011; 2(7):1799-1806.

14. Obadoni BO, Ochuko PO , Phytochemical studies and comparative efficacy of the crude extracts of some haemostatic plants in Edo and Delta States of Nigeria, Global Journal of Pure and Applied Science, 2002; 8(2): 203-208.

15. Kaur C, Kapoor HC, Anti-oxidant activity and total phenolic content of some Asian vegetables. International Journal of Food Science and Technology, 2002; 37:153-161.

16. Chang C, Yang M, Wen H, Chern J, Estimation of total flavonoid content in propolis by two complementary colorimetric methods. Journal of Food and Drug Analysis, 2002; 10: 178-182.

17. Siddhuraju $P$, Manian $S$, The antioxidant activity and free radical scavenging capacity of dietary phenolic extracts from horse gram (Macrotyloma uniflorum (Lam.) Verdc.) seeds. Food Chemistry, 2007; 105(3): 950-958.

18. Makkar HP, Siddhuraju P, Becker K, Methods in molecular biology: plant secondary metabolites. Totowa: Human Press, 2007; p 93-100.

19. Madhu M, Sailaja V, Satyadev TN, Satyanarayana MV Quantitative phytochemical analysis of selected medicinal plant species by using various organic solvents. Journal of Pharmacognosy and Phytochemistry, 2016; 5(2): 25 - 29.

20. Anitha $\mathrm{S}$ and Rajadurai $\mathrm{M}$, In vitro cytotoxicity and glucose uptake activity of Chrysin, A flavones in L6 cell lines. International Journal of Recent Scientific Research, 2017; 8(3):15894 - 15897.

21. Anna TR, Automated Glucose Methods: Evaluation of a glucose oxidase - peroxidase procedure, Clinical Chemistry, 1973; 19(10): 1152 - 1157.

22. Narmatha M, Maneemegalai S, Preliminary analysis of nutrients and phytochemical contents of Syzygium cumini seeds, International Journal of Green and Herbal Chemistry, June 2019 - August 2019; 8(3): 269 - 276.

23. Anitha MM, Sujith K, Santhosh Pillai , Christina AJM, Study of glucose uptake activity of Solanum xanthocarpum in L6 cell lines. European Journal of Biological Sciences, 2013; 5(3): 77 81.

24. Rothman DL, Magnusson I, Cline G, Gerard D, Kahn CR, Shulman RG, and Shulman GI, Decreased muscle glucose transport/ phosphorylation is an early defect in the pathogenesis of noninsulin-dependent diabetes mellitus. Proceedings of the National Academy of Sciences of the United States of America, 1995; 92: 983-987.

25. Cline GW, Magnusson I, Rothman DL, Petersen KF, Laurent D, Shulman GI, Mechanism of impaired insulin stimulated muscle glucose metabolism in subjects with insulin dependent diabetes mellitus. Journal of Clinical Investigation, 1997; 99: 2219-2224.
26. Samuel VT, Shulman GI, Integrating mechanisms for insulin resistance. Common threads and missing links. Cell, 2012; 148: $852-871$.

27. Musi N, Good year LJ, Insulin resistance and improvements in signal transduction. Endocrine, 2006; 29: 73 - 80.

28. Samir AK, Sendra Y, Donald SN, Amie JD, Natural supplements for improving insulin sensitivity and glucose uptake in skeletal muscle. Frontiers in Bioscience, Elite, 2015; 7: 107 - 121.

29. Gupta RN, Pareek A, Rathore GS, Suthar M, Study of glucose uptake activity of Helicteresisora Linn. fruits in L-6 cell lines. The International Journal of Diabetes in Developing Countries, 2009;29:170 -173.

30 . Yarasu N, Smana P, Pavankumar R, Nareshchandra RNBS, Vinil Kumar V, In vitro glucose uptake assay of hydro methanolic leaves extract of Syzygium jambos (L) alston in rat skeletal muscle (L6) cell lines. Indo American Journal of Pharmaceutical Research, 2013; 3(9): 7336-7341.

31. Triveni B, Bhaskarjyoti G, Alak KB, Suman D, Protective and curative effect of Scoparia dulcis leave extract againt free fatty acid induced insulin resistance in rat L6 myotubes. American Journal of Phytomedicine and Clinical Therapeutics, 2014; 2(7): $842-854$.

32. Xu J, Wang S, Feng T, Chen Y, Yang G, Hypoglycemic and hypolipidemic effects of total saponins from Stauntonia chinensis in diabetic $\mathrm{db} / \mathrm{db}$ mice. Journal of Cellular and Molecular Medicine, 2018;22:6026-6038.

33. Liu X, Kim J, Li Y, Li J, Liu F, Chen X, Tannic acid stimulates glucose transport and inhibits adipocyte differentiation in 3T3L1 cells. Journal of Nutrition, 2005; 135: 165-171.

34. ChuHyun Kang, Joo-Hui Han, Joonseok Oh,Roshan Kulkarni, Wei Zhou, Daneel Ferreira, Tae Su Jang, Chang-Seon Myung, MinKyun $\mathrm{Na}$, Steroidal Alkaloids from Veratrum nigrum Enhance Glucose Uptake in Skeletal Muscle Cells. Journal of natural products. 2015; 78(4): 803-810.

35. Md Badrul Alam, Hongyan An, Jeong - Sic Ra, Ji-young Lim, Seung - Hyun Lee, Chi - Yeol Yoo, Sang-Han Lee, Gossypol from cotton seeds ameliorates glucose uptake by mimicking insulin signaling and improves glucose homeostasis in mice with streptozotocin induced diabetes, Oxidative Medicine and Cellular Longevity, 2018; 2018:1-11.

36. Sumiran Kumar Sinha, Imran Ahmad, Gayathri M, Antidiabetic effect of ethanol extract of Syzygium jambolanum seed (in vitro) Int. J. Drug Dev \& Res, 2013; 5(3): 187 - 191.

37. Das MS, Devi G, In vitro Cytotoxicity and Glucose Uptake Activity of Fruits Terminalia bellirica in Vero, L-6 and 3T3 cell lines. Journal of Applied Pharmaceutical Science, 2015; 5(12): 092 095 . 